\title{
Die reg op lewe
}

\author{
J.M. Vorster \\ Skool vir Kerkwetenskappe \\ Potchefstroomse Universiteit vir $\mathrm{CHO}$ \\ POTCHEFSTROOM \\ E-pos: kwsjmv@puknet.puk.ac.za
}

\begin{abstract}
The right to life

This article deals with the practical application of the fundamental right to life with special focus on abortion, capital punishment and euthanasia. From a Christian ethical perspective and the biblical principle of life it is argued that the practice of abortion, capital punishment and euthanasia cannot be justified for various reasons. Christians should therefore consider other ways to deal with issues like unwanted pregnancies and suffering. Regarding serious crime, punitive measures other than capital punishment ought to be considered because the practice of capital punishment can be misused by the state and can lead to the abuse of power. Capital punishment is also detrimental to the development of a culture of respect for life in society at large.
\end{abstract}

\section{Opsomming}

\section{Die reg op lewe}

Hierdie artikel handel oor die praktiese toepassing van die reg op lewe as fundamentele reg. Die fokus val spesifiek op die praktyke van aborsie, genadedood en die argumentering ten gunste van die doodstraf. Vanuit 'n Christelike etiese perspektief en veral die Bybelse beginsel van beskerming van lewe word betoog dat aborsie, ganadedood en die toepassing van die doodstraf om verskillende redes nie regverdigbaar is nie. Christene moet daarom ander weë vind om ongewenste swangerskappe, lyde en geweldsmisdaad te hanteer. Spesifiek ten opsigte van ernstige misdaad moet ondersoek ingestel word na ander gepaste strafmaatreëls omdat die praktyk van doodstraf deur die staat misbruik kan word, soos deur verskeie ondersoeke in hierdie verband aangetoon is. Doodstraf is ook kontra-produktief in die ontwikkeling van 'n kultuur van respek vir lewe in die gemeenskap as geheel. 


\section{Inleiding}

Die Universele Deklarasie van Menseregte waardeur die Verenigde Nasies 'n dinamiese invloed op die na-oorlogse politieke sisteme uitgeoefen het en steeds uitoefen, bepaal in artikel 3: "Everyone has the right to life, liberty and security of person" (United Nations, 1995:153). Hierdie kort en kragtige formulering word gevind in alle huidige regstate se Handveste van Fundamentele Regte. Daar bestaan wye konsensus dat die reg op lewe 'n fundamentele reg is en dat dit deel van die owerheid se taak is om lewe te beskerm.

Die beklemtoning van die reg op lewe is in ooreenstemming met die Bybelse siening van die heiligheid van lewe en die roeping van die mens om lewe te beskerm, te bewaar en tot ontplooiing te bring (vgl. Vorster, 2000:1). Lewe kom van God af en moet as 'n kosbare gawe van God beskerm word (vgl. hieroor Wüstenberg, 1998:124). Uit hierdie hoek gesien, kan gesê word dat lewe 'n voorreg is en nie 'n reg nie omdat God beskikkingsreg oor lewe het (Lategan, 1991:15).

In hierdie artikel word egter aandag gegee aan die praktiese toepassing van die reg op lewe as 'n fundamentele reg. Die erkenning van die reg op lewe in hierdie sin en die wyse waarop daar met die konsep lewe in die hedendaagse politiek omgegaan word, bring eienaardige teenstrydighede mee. Aborsie op aanvraag en eutanasie word in toenemende mate gewettig, terwyl die doodstraf nog in verskeie lande toegepas word, alhoewel die reg op lewe konstitusioneel gerespekteer word. Hiervan is die VSA 'n treffende voorbeeld. Dit blyk dus dat die reg op lewe al hoe meer gereduseer word ten spyte van die algemene erkenning daarvan.

In hierdie artikel word hierdie teenstrydighede Christelik-eties beoordeel. Die sentraal-teoretiese argument wat beredeneer word, is dat die Bybelse beklemtoning van lewe as God se gawe en die konstisionele erkenning van die reg op lewe nie ruimte behoort te laat vir die wettiging van aborsie op aanvraag, die toepassing van doodstraf en die wettiging van eutanasie nie. Die Christen moet op 'n ander wyse met die problematiek rondom sake oor lewe omgaan en die reg op lewe in ere hou. Ten einde hierdie argument te ontvou, word respektiewelik aandag gegee aan die Bybelse perspektiewe en Christelik-etiese perspektiewe op die reg op lewe en aborsie, doodstraf en eutanasie.

\section{Die reg op lewe en aborsie}

Aborsie word in regsterme gedefinieer as "the expulsion of an embrio or fetus before it is viable" (Gross, 2000:247). In 'n tyd waarin die reg op lewe in die menseregtedebat sterk beklemtoon word, het die argumente 
ten gunste van aborsie op aanvraag hand oor hand toegeneem. Meer klem word gelê op die reg van die vrou om te kies of sy met 'n swangerskap wil voortgaan as op die "reg" van die ongebore kind. In meer en meer regstate word aborsie op aanvraag gewettig. Beckwith (2001:21) wys daarop dat die huidige beredenering van die wettigheid van aborsie op aanvraag uitgaan van die standpunt dat die argumente ontdaan moet word van "metafisiese" argumente en bloot op realistiese positivistiese wyse gevoer moet word. Godsdiens moet dus uit die saak gehou word. 'n Voorstander van hierdie beskouing is Simmons (2000: $69)$.

Argumente wat op grond van hierdie uitgangspunt ten gunste van aborsie op aanvraag gevoer word, kan in die volgende kategorieë verdeel word (Douma, 1996:219):

- Die mediese argument. Hiervolgens kan daar, wanneer die lewe van die ma of die kind bedreig word, aborsie toegepas word. In so 'n geval word aborsie oor die algemeen as geregverdig beskou.

- Die psigologiese argument. Hierdie argument word aangebied wanneer die oortuiging bestaan dat ' $n$ volgehoue swangerskap die vrou psigologies kan skaad. Die vraag is dan of aborsie in so 'n geval geregverdig is. Hieroor bestaan verskil van opinie.

- Die eugeniese argument. Hierdie argument kom ter sprake wanneer die oordeel bestaan dat die kind met 'n ernstige gebrek gebore kan word. In sommige gevalle word aborsie dan as die natuurlike uitweg beskou.

- Die juridiese argument. Hierdie argument is ter sprake wanneer die swangerskap die gevolg is van verkragting en word oor die algemeen ook aanvaar as 'n regverdiging van aborsie.

- Die sosiale argument. Met hierdie argument word betoog dat daar vanweë armoede of ander swak sosiale omstandighede geen toekoms vir die kind bestaan nie. Aborsie sou dan in so 'n geval die beste keuse vir die moeder en kind wees omdat hulle toekoms in elk geval uitsigloos is.

- Die pragmatiese argument. 'n Argument, wat die "pragmatiese argument" genoem kan word, kan by hierdie argumente gevoeg word. Die argument lui soos volg: Daar word in elk geval in arm gemeenskappe soveel "agterstraataborsies" uitgevoer en omdat dit in talle gevalle lei tot die dood van die ma en die kind, is dit beter om dit te 
wettig sodat aborsie in beheerde mediese omstandighede uitgevoer kan word.

Hierdie argumente word gevoer rondom die toenemende wettiging van aborsie op aanvraag. Twee vrae kan in hierdie stadium van die betoog gevra word, naamlik: Is die argumente soos hierbo gevoer "ontdaan van metafisiese elemente"? Gaan dit nie hier ook maar om filosofiese voorveronderstellings oor begrippe soos mens, kind, lewe, lyding en sosiale konteks nie? Beckwith (2001:25) argumenteer op goeie gronde dat dit wel die geval is. Die tweede vraag is: Word hiermee nie die reg van lewe geskend nie?

Hierdie vrae en ander word in die volgende paragrawe behandel en die uitgangspunt is dat, soos Beckwith (2001:25) stel, dit nie anders as uit 'n "metafisiese" hoek benader kan word nie. Die benadering in hierdie geval is dus vanuit die hoek van die Christelike etiek.

\subsection{Bybelse perspektiewe}

'n Etiese beoordeling van aborsie moet uitgaan van die vraag hoe die embrio en fetus gesien word (Rheeder, 1999:324). Is die embrio en fetus 'n mens? Kan aan die embrio en fetus enige waarde toegeken word in die sin dat dit beskermenswaardig is? Op grond van 'n vergelykende studie van verskillende bronne toon Rheeder (1999:325) aan dat daar hoofsaaklik twee opvattings bestaan oor die begin van lewe. Vir die een groep begin lewe met konsepsie wat beteken dat lewe vanaf konsepsie staan onder die beskerming van die sesde gebod, terwyl vir die ander groep lewe op 'n later stadium ontstaan. Hiervolgens is die sesde gebod eers op ' $n$ latere stadium van toepassing. Die konsekwensie van hierdie standpunte is dat daar ook twee opvattings sal wees oor die regsposisie van die embrio en fetus.

Direkte Skrifgegewens hieroor is skaars. Die Skrif is nie 'n biologiese handboek wat hom uitspreek oor die fisiologiese en psigologiese ontwikkeling van die mens nie, maar die besondere openbaring van God se reddende genade in Christus. Tog toon Rheeder (1999:345) in sy omvattende studie aan dat daar wel Skrifgedeeltes is wat as Skrifberoep kan dien vir die standpunt dat die embrio en fetus volledig mens is.

Opsommenderwys kan op die volgende twee direkte Skrifgedeeltes gewys word1:

1 Afleidings uit ander Skrifgedeeltes word dikwels deur Christelike etici gemaak ten opsigte van die liefdesgebod, die aanvaarding van lyding en die aanvaarding van die kind as 'n geskenk uit die hand van die Here (sien hieroor Rheeder, 1999:354 e.v.). Hoewel hierdie argumente belangrik is in die breë beoordeling van aborsie, word dit 
- Job 3:3:

Die dag waarop ek gebore is, moes nooit aangebreek het nie, die nag toe gesê is 'n seuntjie het in die wêreld gekom.

Die uitdrukking "in die wêreld kom", beteken eintlik "swanger gemaak is". Steun vir hierdie woordeksegese word gevind by Skrifverklaarders soos Driver en Gray (1921:31-32); Van Selms (1952:39-40) en Hartley (1988:92). Kress (1999:37) betoog ook op grond van Jesaja 45:18 dat die Here alles (ook die kind) vorm uit niks. Alles wat van konsepsie af plaasvind, is deel van God se vorming van 'n mens. Daarom word ook in Eksodus 22:21 'n straf voorgeskryf vir die een wat 'n swanger vrou so beseer dat sy 'n miskraam het. Uit hierdie Skrifgegewens kan dus afgelei word dat die mens in die wêreld kom met konsepsie wat op geslagsgemeenskap volg en nie eers met geboorte nie.

\section{- Psalm 139:13-16.}

$U$ het my gevorm, my aanmekaargeweef in die skoot van my moeder. Ek wil $U$ loof, want $U$ het my op 'n wonderbaarlike wyse geskep. Wat $U$ gedoen het, vervul my met verwondering. Dit weet ek seker: geen been van my was vir $U$ verborge toe ek gevorm is waar niemand dit kon sien nie, toe ek aanmekaargeweef is diep in die moederskoot. $U$ het my al gesien toe ek nog ongebore was, al my lewensdae was in u boek opgeskrywe nog voordat ek gebore is.

Hierdie verse dui op God se betrokkenheid by die mens vanaf die swangerskap. Hierdie betrokkenheid gee waarde aan die embrio en fetus. Die gedagte dat die embrio van die begin af mens is, word ook gevind in Psalm 51:7 waar die doemwaardigheid van die mens van sy ontvangenis af beskrywe word. Die embrio is dus reeds vanaf konsepsie sowel objek van God se bemoeienis as doemwaardig op grond van die erfsonde.

Benewens die enkele direkte Skrifgegewens kan vanuit die geheel van die Bybelse perspektief ook ander argumente oor aborsie gevoer word. Die eerste argument handel oor die siel-liggaamproblematiek. Uitgaande van die standpunt dat die mens eers mens is wanneer die siel by die liggaam gevoeg word, word die vraag ook gevra op watter stadium van die voorgeboortelike ontwikkeling die siel by die liggaam gevoeg word. Indien dit op 'n latere stadium in die ontwikkeling van die embrio en fetus is, sou die embrio en fetus nie as mens gesien kan word totdat die siel

hier nie weer beredeneer nie, omdat dié argumente nie gaan om die wesenlike wat hier aan die orde is nie, naamlik of die embrio en fetus tydens die eerste veertien weke beskou moet word as 'n mens nie. Bogenoemde tekste word hanteer omdat dit dié vraag behandel. 
nie daarby gevoeg is nie. Rheeder (1999:329) toon egter aan dat hierdie argumentasie uitgaan van 'n dualistiese mensbeskouing waarin die liggaam en siel as twee entiteite beskou word. Die Bybelse mensbeskouing tipeer die mens as 'n eenheidswese. Daar is nêrens in die ontwikkeling van die mens vanaf konsepsie 'n stadium waar dit sonder 'n siel is nie. Die argument dat die embrio en fetus minderwaardig is omdat dit nog nie 'n siel het nie, kan dus nie Christelik-eties begrond word nie.

Banner (1998:26 e.v.) belig die saak van aborsie vanuit 'n ander Bybelse perspektief, naamlik die perspektief van die Christelike hoop. Op grond van die Bybelse beskouing dat Christus die eerste en die laaste is en dat sy koningsheerskappy oor alle dinge geld, word die troos aan die mens gegee om nie te vrees nie. Christus is die fundering en inspirasie van Christelike hoop. Die gelowige moet hierdie hoop beleef, uitleef en uitdra. Sowel aborsie as eutanasie is dade wat deur wanhoop gedryf word en daarom is dit teen die essensie van die hoop wat Christus aan 'n gebroke wêreld bied. Hierdie tematiese benadering van Banner is van waarde en kan met reg aangewend word in 'n Christelike beoordeling van die reg op lewe (sien hieroor ook Vorster, 2000:1-23).

'n Argument wat in Christelike kringe gebruik word om die wettiging van aborsie op aanvraag te verdedig is 'n beroep op Genesis 2:7. Op grond van hierdie Skrifgedeelte word beweer dat die fetus eers mens word as dit self kan asemhaal. Fletcher is 'n eksponent van hierdie siening. Hy sê: "Therefore, Jewish and biblical tradition defined a human being with the word 'nephesh' - the breathing one" (Beckwith, 2001:25). Die argument is egter in hierdie sin nie geldig nie, want die "nephesh" dui op lewe en nie op asemhaling in biologiese sin nie. God het die mens wat Hy geskape het 'n lewende mens gemaak.

\subsection{Etiese perspektiewe}

Die Christelike etiek behoort primêr die aborsiedebat te voer vanuit die Christelike mensbeskouing. Die Christelike mensbeskouing rus op die mens se beeldskap van God. Omdat die mens die beeld van God dra, mag sy lewe nie geneem word nie. Hierdie beginsel ken dus 'n intrinsieke waarde aan die embrio en fetus toe. Op grond van die argument kan die intrinsieke waarde van die embrio en fetus dan beredeneer word langs die weg deur Lee (1996:24) voorgestel. Oor intrinsieke waarde redeneer hy soos volg:

1. The foetus is identical with - that is, one and the same entity as - the being who is later rational and self-conscious.

2. The being who is later rational and self-conscious is, at that later time, intrinsically valuable. 
3. If a thing is intrinsically valuable, then it is intrinsically valuable from the moment that it exists.

4. So, the being who is later rational and self-conscious is intrinsically valuable from the moment that it exists. (From (2) and (3).)

5. Therefore, the foetus is intrinsically valuable from the moment that it exists. (From (1) and (4).) (Vgl. ook Stretton, 2000:239.)

Volgens hierdie argumentasie moet dus afgelei word dat die embrio en fetus "'n toekoms van waarde" het soos in die bio-etiek betoog word (Brown, 2000:103). As sodanig is die embrio en fetus mens en daarom volgens die Christelike antropologie ook beelddraer van God. Vernietiging van die embrio en fetus is dus gelyk aan die neem van die lewe van 'n mens en 'n oortreding van die sesde gebod. Andersyds moet ook gekonkludeer word dat die embrio en fetus as mens ook die reg het op lewe.

Vanuit bio-etiese hoek volg Wendler (1999:33) 'n ander argumentasielyn. Sy beswaar teen aborsie berus nie op die argument dat die embrio en fetus ' $n$ persoon is of op die intrinsieke waarde van die embrio en fetus nie, maar op die "morele status van die proses van fetale ontwikkeling" (Wendler, 1999:44). Sy argument loop soos volg:

1. The deliberate interruption of an instance of a natural process which, as a kind of process, helps define the fundamental structure of our lives is prima facie seriously immoral.

2. Fetal development, as a kind of natural process, helps define the fundamental structure of our lives.

3. Abortion constitutes a deliberate interruption of an instance of fetal development.

4. Therefore, abortion is prima facie seriously immoral (Wendler, 1999:38 en 50).

Die argument van Wendler hoef nie, soos hy betoog, die argument van die persoonskap van die embrio en fetus te vervang nie. Die argument wat uitgaan van die persoonskap van die embrio en fetus en die argument wat uitgaan van die morele status van die proses kan mekaar aanvul in die afwysing van aborsie op aanvraag.

Benewens die feit dat aborsie die beëindiging van die lewe van 'n ander mens is, is dit ook 'n selfdestruktiewe handeling. $\mathrm{Na}$ 'n psigologiese en sosiologiese gevallestudie kom Avalos tot die volgende konklusie: "Years following the procedure, some women are quite satisfied with their abortion decisions while others articulate primary emotions of loss or grief rather than relief" (Avalos, 1999:51). Jeffrey (1999:29) toon na 'n 
soortgelyke studie aan dat van die volgende simptome algemeen voorkom by vroue wat aborsie ondergaan het: skuldgevoelens; depressie; dwelmmisbruik; alkoholmisbruik; gevoelens van skaamte; angs; terugflitse van die aborsie; pre-okkupasie met die dood; gebrek aan seksuele intimiteit; bulimia; anoreksia; neiging tot ' $n$ vinnige swangerskap as vervanging van die vorige kind; obsessies met ander kinders; nagmerries; vermyding van kinders; selfdestruktiewe gedrag; selfmoordgedagtes; woede en gevoelloosheid. In Boeddhistiese gemeenskappe in Japan bestaan die sogenaamde mizuko kuyô, 'n religieuse ritueel wat vrouens wat aborsie ondergaan het, uitvoer om van hulle skuldgevoelens ontslae te raak (LaFleur, 1998:797). Die feit dat daar so 'n ritueel bestaan, is 'n bewys van die feit dat vroue wat aborsie ondergaan, ook selfdestruktief optree. Hierdie selfdestruksie is op sigself ook 'n oortreding van die sesde gebod.

Verder kan geargumenteer word dat die reg van aborsie op aanvraag rus op 'n individualistiese mens- en samelewingsbeskouing. Die reg van die vader word misken. Ook die Bybelse verband tussen die verbondsgesin en die breë verbondsgemeenskap van gelowiges word uit die oog verloor. Kindskap by die gelowige beteken ook meerdere meelewing deur medegelowiges en die beëindiging van lewe sonder inspraak van die meerdere belewing druis in teen die Christelike samelewingsbeskouing. Juis daarom wys Jeffrey (1999:28) daarop dat vroue wat na 'n aborsie aan bogenoemde simptome ly, verligting vind wanneer hulle hulle skuld bely aan die "mense om hulle", en in besonder aan die vader van die kind.

Die Bybelse en etiese gegewens oor aborsie dui aan dat die wettiging van aborsie op aanvraag in stryd is met die owerheid se taak om die reg op lewe te beskerm. Die reg van die moeder om self te kies word verabsoluteer. In 'n Christelike teorie van menseregte kan 'n reg nooit absoluut word nie, want dan word die fyn balans tussen verskillende regte en die verhouding tussen reg en plig skeefgetrek. Die wettiging van aborsie op aanvraag, juis in die moderne tyd waar menseregte, en daarmee saam die reg op lewe, hoog geag word, bring 'n onverstaanbare kontradiksie mee (Beckwith, 2001:19). Dit blyk dat blote pragmatisme hier die oorhand het oor gefundeerde etiese denke.

Die afwysing van aborsie op aanvraag kan egter ook nie absoluut geld nie. Die onvermydelike saak van botsing van pligte waar soms gekies moet word vir die minste van twee euwels is hier ook ter sprake (De Bruyn, 1998:127). In sommige gevalle moet aborsie wel toegelaat word. In hierdie opsig kan verwys word na 'n situasie waar die lewe van die moeder of die kind of albei in gevaar verkeer. Dan moet 'n keuse tussen die lewe van die moeder en die kind gemaak word. Vanweë die moeder 
se verpligtinge en onmisbaarheid vir die res van die gesin word aborsie dan as die enigste uitweg gesien. Ook by swangerskap na verkragting blyk aborsie toelaatbaar te wees omdat die voortgesette swangerskap vir die moeder groot psigo-sosiale konflik tot gevolg kan hê. In hierdie twee gevalle kon die swangerskap nie verhoed gewees het nie - eersgenoemde omdat die swangerskap bona fide beplan is en laasgenoemde omdat die swangerskap met geweld veroorsaak is.

'n Botsing van pligte moet egter slegs in die uiterste situasies as argument voorgehou word. Die vier ander redes wat gewoonlik aangegee word is: moontlike gestremdheid van die kind, armoede, die ongetroude status van die vrou en die vrou se keuse om nie meer kinders te hê nie (Sullins, 1999:354). In hierdie gevalle kon die swangerskap deur beplanning voorkom gewees het. Argumente ten gunste van aborsie in hierdie gevalle rus dus op suiwer pragmatiese gronde. Sulke argumente kan so wyd geïnterpreteer word dat feitlik enige aborsie op aanvraag moontlik is. So 'n bloot pragmatiese benadering bring die Bybelse beskouing oor die belangrikheid van lewe in gedrang en as gevolg daarvan word die effektiewe beskerming van die kind se reg op die lewe aan bande gelê.

In die lig van dié etiese perspektiewe behoort die Christen pro-aktief op te tree deur gesinsbeplanning, morele waardes oor seksualiteit en die idee van heiligheid van lewe aktief te bevorder. Mense moet gewys word op hulle taak tot bewaring en ontvouing van lewe en die skadelike gevolge wat aborsie vir 'n gemeenskap het. Hieroor moet ook teenoor die owerheid getuig word.

\section{Die reg op lewe en doodstraf}

In die Christelike etiek was doodstraf onder bepaalde omstandighede as geregverdig beskou (Van Wyk, 1991:267). Oor die eeue heen het kerke oor die algemeen die reg van die staat erken om die doodstraf toe te pas (Dinn, 2000:32). Tans is daar wêreldwyd 'n pleidooi dat doodstraf heeltemal afgeskaf moet word. Hierdie pleidooi is onlangs voor die Menseregtekomissie van die Verenigde Nasies deur Chirac verwoord. Hy het gesê:

On the death penalty, too, we must make progress. More than 100 countries have abolished it and every year three or four more States join their ranks as the conviction takes hold that death cannot under any circumstances constitute an act of justice. In addition, no justice is infallible and every execution may be killing an innocent person. And what are we to make of executions of minors and the mentally deficient? I call for universal abolition of the death penalty, with, as a first step, a general moratorium (Chirac, 2001:7). 
Die volgende argumente teen die doodstraf word genoem:

- Doodstraf kan deur totalitaristiese owerhede misbruik word om politieke opponente uit die weg te ruim.

- Doodstraf kan met vooroordele toegepas word. In 1972 het die hooggeregshof van die VSA byvoorbeeld gesê dat die toepassing van die doodstraf onder die bestaande wette van daardie tyd in die state Georgia en Texas "arbitrary en conspicuous" was (Dieng, 1997:167).

- Vanweë die feilbaarheid van regstelsels kan foute wat gemaak is in die verhoor en vonnis van 'n mens nie weer reggestel word as so 'n persoon tereggestel is nie.

- Doodstraf pas nie in by die moderne samelewing waar 'n etos van die waarde van lewe gekweek moet word nie.

- Doodstraf neem die moontlikheid van berou, bekering en restitusie weg .

- Daar is geen wetenskaplike bewys dat doodstraf 'n effektiewe afskrikmiddel is vir ernstige misdaad nie.

\subsection{Bybelse perspektiewe}

Gaie (1996:367) beroep hom op verskeie outeurs vir sy bewering dat slegs die Nuwe-Testamentiese gegewens oor die doodstraf geldig is omdat die Nuwe-Testamentiese etiek dié van die Ou Testament vervang het. In die Nuwe Testament vind hy dan geen bewys vir die reg tot doodstraf nie. Hierdie standpunt kan nie aanvaar word nie omdat die Bybel self in Hebreërs 1:1 die eendersheid en andersheid van die twee Testamente uitspel. Albei moet gelees word in die lig van die volle openbaringsgeskiedenis van die Bybel. Hoewel die etiek van die Ou Testament nie op biblistiese en fundamentalistiese manier hanteer moet word nie, is die etiese perspektiewe van die Ou Testament in die lig van die volle openbaring van die Skrif steeds geldig en moet dié getuienis ten opsigte van die doodstraf in berekening gebring word.

Doodstraf was 'n bekende vorm van straf in die Ou-Testamentiese strafreg. In die Oosterse milieu is doodstraf as algemeen aanvaarbaar geag en is dit vir 'n wye verskeidenheid van handelinge toegepas. In die Ou Testament is doodstraf toegeken vir die volgende handelinge:

- Moord met voorbedagte rade (Gen. 9:5-6; Eks. 21:12 e.v.; Lev. 24:17; Num. 35:16-21; 30-33; Deut. 17:6, 19);

- owerspel (Lev. 20:10; Deut. 22:21-24);

- bloedskande (Lev. 20:11, 12, 14); 
- bestialiteit (Eks. 22:19; Lev. 20:15-16);

- sodomie (Lev. 18:22; 20:13);

- die verkragting van 'n verloofde meisie (Deut. 22:25).

- ontvoering met die oog daarop om iemand as slaaf aan te hou (Eks. 21:16; Deut. 24:7).

- kwaadwillige getuienis in verband met ontrou aan die Here (Deut. 19:16-20);

- 'n priesterdogter wat hoereer (Lev. 21:9);

- towery (Eks. 22:18);

- kinderoffer (Lev. 20:2-5);

- diegene wat hulle pa of ma slaan of vloek (Eks. 21:15, 17; Lev. 20:9; Spr. 20:20);

- volhardende ongehoorsaamheid aan ouers en owerhede (Deut. 17: 12 ; $21: 18-21$ );

- laster (Lev. 24:11-14, 16, 23);

- afgodediens (Eks. 22:20; Lev. 20:2);

- valse profesie (Deut. 13:1-10);

- algemene wetteloosheid (Deut. 17:12);

- versteekte onkuisheid (Deut. 22:20-21)'

- ontheiliging van die Sabbat (Eks. 35:2; Num. 15:32-36).

- dodebeswering (Lev. 20:27; vgl. Deut. 18:10 e.v.).

De Vaux (1988:158) deel hierdie sondes in in drie groepe, naamlik sondes teen God, sondes teen mense en sondes teen ouers. Anders as die $\mathrm{Ou}$ Oosterse wette is doodstraf by die Israeliete beperk tot oortredings teen die suiwerheid van aanbidding, die heiligheid van lewe en die bronne van lewe.

Daar was wel duidelike beperkings gestel op die uitvoering van die doodstraf. Douma (1996:236) dui aan dat slegs een getuie nie as genoegsaam beskou is om die doodstraf toe te pas nie (Num. 35:30). Die oudstes en 'n "bevoegde vergadering" moes by die verhoor betrokke wees en daar moes vasgestel word of die moord met voorbedagde rade gepleeg is (vgl. Deut. 19:12; Num. 35:12; Jos. 20:4 en 6). Waar doodslag sonder intensie plaasgevind het, kon die persoon wat die daad gepleeg het, na een van die asielstede vlug. 
Daar was ook begenadiging vir mense wat skuldig was aan die misdrywe waarvoor doodstraf toegeken is. Kain het sy broer vermoor en is nie daarvoor met die dood gestraf nie (Gen. 4:15). Moses het moord gepleeg en is nie daarvoor tereggestel nie (Eks. 2). Dawid se sluwe manier om Uria uit die weg te ruim, het hom nie die doodstraf op die hals gehaal nie en hy het geleentheid gekry vir berou en bekering (Ps. 51).

Twee Bybelse perspektiewe wat tradisioneel gebruik is en gebruik word om doodstaf te regverdig, is Genesis 9:6 en Romeine 13. In sy verklaring van Genesis 9:6 sê Calvyn (1847:295) dat dié gedeelte nie handel oor algemene wraaksug nie, maar oor die doodstraf wat die reg moet voorskryf en wat die owerheid moet uitvoer. Hierdie standpunt is in die gereformeerde etiek sedert Calvyn gehuldig (sien Douma, 1996:234).

Wenham (1987:192) is van mening dat Genesis 9:6 die uniekheid van menslike lewe uitspel. Die mens se lewe is uniek juis omdat die mens geskape is na die beeld van God. Daarom moet moord met doodstraf gestraf word. Hoewel Westermann (1972:90) van oordeel is dat moord 'n ingrype is in die reg van God oor lewe en dood, meen hy dat die klem in die vers primêr lê op die verbod op doodmaak eerder as op die straf. In sy latere werk ken hy egter, met verwysing na Matteus 26:59, meer waarde aan die strafbepaling en die motivering in die vers toe (Westermann, 1986:86).

Wie moet die doodstraf volgens Genesis 9:6 toepas - God of 'n ander mens? Hamilton (1991:315) weeg die standpunte hieroor op en kom dan tot die volgende konklusie:

On the one hand, most of the modern versions read, 'by man' [be adam] shall his blood be shed. As such, this verse has become the scriptural locus classicus for capital punishment. It is the lex talionis in operation. The penalty must be commensurate with the crime. A life taken demands the taking of another life. On the other hand, some suggest that be adam does not mean 'by man' but (in exchange) for 'that man'. In other words, this verse does not at all delegate authority to man to institute capital punishment. The implication of 'for that man his blood shall be shed' is that God wil administer the punishment. The weakness in this interpretation is that it ascribes to the preposition be an unusual meaning when one of the standard uses of be makes sense in the verse. Also, if v. 6 is ascribing responsibility to God for meting out punishment, then the verse is essentially a tautology of v. 5 . We prefer to see vv. 5 and 6 together, with both prohibiting the taking of human life. The penalty for shedding blood may be exacted either by God (v. 5) or by man (v. $6)$. 
$\mathrm{Na}$ regspraak is die uitvoering van die doodstraf oorgelaat aan die wreker van die bloed wat gewreek moes word. Verskillende wyses van teregstelling is toegelaat asook verdere vernedering van die liggaam van die persoon wat tereggestel is. De Vaux (1988:159) gee hieroor die volgende feite:

Stoning is ordered for idolaters (Dt. 13:10-11; 17:5-7), for blasphemers (Lv. 24:14, 23), for a woman who concealed the fact that she was not a virgin at the time of her marriage (Dt. 22:21), for the guilty fiancée and her accomplice (Dt. 22:24), for the rebellious son (Dt. 21:21) and the man who profaned the sabbath (Nb. 15:35-36). A man who disobeyed an order of extermination and one who was guilty of lese-majesty were also stoned, according to Jos. 7:25 and 1 Kings $21: 10$. It was the normal method of execution and it must also be presumed when the text does not state it precisely (cf. Jn 8:5 for the woman taken in adultery). The condemned person was taken out of the town (1 K. 21:10, 13; cf. Lv. 24:14; Nb. 15:36). The witnesses for the prosecution cast the first stones and the people continued till death ensued. The collective character of communal justice was thus expressed to the end.

Ook ten opsigte van Romeine 13 sê Calvyn (Inst. IV:XX:10:568; vgl. Calvyn, 1949) dat die reg van doodstraf hieruit afgelei kan word. Hy is van oordeel dat die swaardmag waarvan in Romeine 13 sprake is, wys op die reg van die owerheid om die doodstraf uit te oefen. God is die wetgewer wat aan sy "dienaars" die swaard gee om dit teen moordenaars te gebruik. Hy kom tot hierdie konklusie deur te wys op verskeie Ou-Testamentiese tekste waar die owerheid doodstraf toegepas het. Die gereformeerde etiek het hom oor die algemeen ook hierin nagevolg. Douma (1996:235) verwoord hierdie tradisionele siening met sy standpunt dat die swaard moord voorkom. Hy verwys hiervoor na die Heidelbergse Kategismus Sondag 40, vraag 105 waarin die betekenis van die sesde gebod soos volg uiteengesit word:

Vraag: Wat eis God in die sesde gebod?

Antwoord: Ek mag nie self en ook nie deur iemand anders my naaste onteer, haat, beledig of doodmaak nie. Ek mag dit nie met my gedagtes, woorde of gebare doen nie en nog minder met die daad. Ek moet alle wraaksug laat vaar. Ek mag ook myself nie kwaad aandoen of moedswillig in gevaar begewe nie. Daarom dra die owerheid die swaard om doodslag te weer (Ursinus \& Olevianus 1992:549).

Hoe moet oor al hierdie Skrifgedeeltes geoordeel word? Douma (1996:238) is van oordeel dat die lys van misdrywe waarvoor doodstraf in die $\mathrm{Ou}$ Testament toegeken is, tydsgebonde en eie was aan die 
Israelitiese kultuur soos baie ander sedes- en heiligheidswette. Dié opdragte is nie meer normatief vir vandag nie. Wat oorbly, is die beroep op Genesis 9:6 en Romeine 13. Oor die beroep op Genesis 9:6 en Romeine 13 as regverdiging van die doodstraf vandag kan egter ook anders geoordeel word. Die volgende argumente kan in hierdie opsig aangebied word:

- Die Ou-Testamentiese regspraak moet beoordeel word in die lig van die Teokrasie. Die burgerlike reg en die geestelike was vermeng en die terreine van die godsvolk en die staat was nie so geskei soos dit die geval is met die Nuwe-Testamentiese kerk nie. In die Christeliketiese samelewingsleer word die teokrasie nie meer as normatief vir 'n moderne samelewingsleer gestel nie. Die teokrasie vind sy volle vergestalting in die hoofskap van Christus oor die koninkryk en die kerk as die volk van die koninkryk. Vir die burgerlike regering moet norme afgelei word uit die sedelike beginsels van die Bybel met inagneming van die geheel van die Bybelse boodskap en die kultuurhistoriese agtergrond. Genesis 9:6 stel duidelik 'n breë beginsel waarin die belangrikheid van lewe en die verbod op doodslag uitgespel word. Of daaruit afgelei moet word dat die doodstraf deur alle owerhede in alle tye vir doodslag toegepas moet word, kan bevraagteken word. In die Bybel self is dit immers nie gedoen nie.

- Ten opsigte van die beroep op Romeine 13 om die doodstraf te regverdig kan met reg gevra word of die swaardmag, waarvan hier sprake is, werklik dui op die reg tot doodstraf? Dunn (1988:772) toon aan dat hierdie bekende gedeelte handel oor die gesagsverhouding tussen owerheid en onderdaan, veral in die lig van die feit dat die Jode 'n minderheidsgroep was in die Romeinse bestel. Die historiese situasie is hier van besondere belang (vgl. Botha, 1991:241). Die Jode moes, ten spyte van hulle omstandighede, die Romeinse owerheid beskou as dienaars van God wat regspraak moet beoefen ten einde orde en geregtigheid in die samelewing op te bou. Daarom moes hulle selfs aan díe vreemde owerheid gehoorsaam wees. Hulle moes die regspraak van die Romeinse owerheid erken omdat alle gesag deur God ingestel is. Romeine 13 handel dus oor gesonde gesagsverhoudinge en hieruit kan nie noodwendig afgelei word dat die owerheid die reg het om doodstraf toe te pas nie.

Hoogstens kan op grond van die Bybelse perspektiewe gesê word dat die owerheid die doodstraf mag toepas, maar dat dit nie 'n gebod is nie. In die Bybelse geskiedenis self is die doodstraf immers nie as ' $n$ gebod toegepas nie. 


\subsection{Etiese perspektiewe}

Met inagneming van bogenoemde Bybelse gegewens kan die volgende argumente gevoer word om tot die konklusie te kom dat die doodstraf in die hedendaagse samelewing nie toegepas behoort te word nie:

- Die bevooroordeelde toepassing van die doodstraf is 'n wesenlike gevaar. In die VSA wat beskou word as die mees ontwikkelde demokrasie in die Wêreld word die doodstraf tans nog in 38 state toegepas (Dieng, 1997:168). In 'n ondersoek deur 'n internasionale regskommissie oor die toepassing van die doodstraf in die VSA word egter ontstellende feite aan die lig gebring. Na die saak Furmann vs Georgia in 1972 kom regter Douglas tot die konklusie:

It is the poor, the sick, the ignorant, the powerless and the hated who are executed. One searches in chronicles in vain for the execution of any member of the affluent section of the society (International Commission of Jurists, 1997:174).

Hoewel die regspraak na hierdie saak in die onderskeie state en in die Federale hof hierna hersien is, het dit nog nie die voorkoms van bevooroordeelde regspraak uitgeskakel nie. In 1980 merk regter Brennan op: “... the disgraceful distorting effects of racial discrimination and poverty continue to be painfully visible in the imposition of death sentences" (International Commission of Jurists, 1997:176). Veelseggend is die bevinding van die Baldus-studie na die uitspraak in die saak McKlesky vs Kemp in 1987. Hieroor sê die kommissie:

According to the study defendants of either race who killed white victims were more than four times as likely to receive the death penalty as were defendants whose victims were black. Moreover, black defendants convicted of killing white victims had the greatest likelihood of being sentenced to death (International Commission of Jurists, 1997:177).

Bevooroordeelde toepassing van die doodstraf is dus ' $n$ wesenlike probleem.

- Daar bestaan genoegsame ander moontlikhede van swaar straf vir moordenaars. Die strafstelsel is vandag anders as in die tyd van die $\mathrm{Ou}$ Ooste. Gevangenisstraf was onbekend in die Mosaïese wet (Douma, 1996:238). Tans kan 'n moordenaar lewenslank uit 'n samelewing verwyder word deur middel van gevangenisstraf. Doodstraf vir moord met verswarende omstandighede behoort dus vervang te word deur lewenslange gevangenisstraf. 
- Kommer oor die wyse waarop doodstraf in die onlangse verlede en in die hede misbruik word, neem wêreldwyd toe. Saletan (2000:7) sê hieroor: "People who support the death penalty in principle are getting cold feet about its application because they are coming to doubt that the government makes these decisions wisely". Doodstraf ten einde politieke opposisie uit te skakel kom nog gereeld voor. Misbruik van die doodstraf is 'n ernstige vergryp teen die reg op lewe.

- Die doodstraf is onherroeplik. Indien daar in die regsraak foute gemaak is, kan die foute nie weer reggestel word nie.

- Empiriese navorsing bewys dat die doodstraf min afskrik-effek het (Bondolfi, 1999:786).

- Daar kan ook geoordeel word dat die doodstraf op sigself lewe goedkoop maak. Die owerheid moet juis die heiligheid van lewe in hoë aansien hou en die uitoefening van die doodstraf skep by die onderdane die indruk dat lewe goedkoop is. In sy beroep dat die doodstraf beperk of afgeskaf moet word, voer Pous Johannes Paulus II byvoorbeeld aan dat die afskaffing van die doodstraf meer in ooreenstemming is met menswaardigheid. Die owerhede moet menswaardigheid bevorder en daarom versoek hy dat effektiewe strafstelsels eerder ontwikkel moet word om misdaad te bekamp. Dinn (2000:33) beredeneer hierdie standpunt verder en sê dat alle lewe heilig is - ook die lewe van die skuldige. Alle vraagstukke oor die beskerming van lewe is intens verweef soos 'n soomlose kleed. Die samelewing kan nie aan die een kant lewe hoog ag en aan die ander kant 'n mens van sy lewe ontneem nie.

Ook ten opsigte van die toepassing van die doodstraf, soos met aborsie, kom die botsing van pligte dus ter sprake. Hoewel die Bybel die reg van die owerheid erken om doodstraf toe te pas moet, in die lig van bogenoemde gevare, ander weë ondersoek word. In die plek van doodstraf kan eerder ander strafmetodes soos lewenslange gevangenisstraf oorweeg word. In verskeie gemeenskappe word alternatiewe strawwe met sukses toegepas (Allman, 1998:22). Lewenslange gevangenisstraf skakel die leemtes van doodstraf effektief uit. Hierdeur word die mag van die owerheid beperk om die doodstraf te misbruik vir ander doeleindes of bevooroordeeld toe te pas en word die geleentheid vir regstelling gebied indien 'n verkeerde uitspraak en vonnis gemaak is.

\section{Die reg op lewe en eutanasie}

Eutanasie kan vir die doeleindes van Christelik-etiese ondersoek getipeer word as "selfmoord met die hulp van 'n ander persoon" (Tristan Engelhardt, 1998:115). Eutanasie word tans al hoe meer onder die 
soeklig geplaas, veral nadat die Nederlandse Eerste Kamer die toepassing daarvan in sekere omstandighede gewettig het. Hoe moet hierdie saak in die lig van die reg op lewe beoordeel word? Bring die erkenning van die reg op lewe in die moderne konsep van 'n regstaat en die toelating van eutanasie nie 'n onhoudbare teenstrydigheid mee nie?

Die argument ten grondslag van eutanasie is tweërlei. Eerstens word geoordeel dat 'n mens in 'n siektetoestand kan kom dat hy/sy soveel pyn verduur dat voortgesette lewe ondraaglik geword het. Tweedens word die argument aangevoer dat 'n mens vanweë sy/haar ongeneeslike siekte nutteloos voel en dat dit lei tot psigiese wroeging (vgl. Douma, 1996:221). Om so 'n mens se lewe te beëindig word dan as 'n daad van genade gesien.

In die jongste verlede het Christelike etici die onderskeid gemaak tussen aktiewe en passiewe eutanasie (vgl. Fischer, 1996:110). Aktiewe eutanasie wys op die handeling van iemand wat daadwerklik die lewe van 'n ander beëindig. Aktiewe eutanasie sou dan plaasvind wanneer, byvoorbeeld ' $n$ medikus, deur 'n dodelike inspuiting die lewe van 'n lydende mens tot ' $n$ einde bring. Passiewe eutanasie gebeur wanneer alle behandeling gestaak word en 'n persoon sodoende toegelaat word om te sterf. Die standpunte word ook vervolgens in die lig van Bybelse en etiese perspektiewe beoordeel.

\subsection{Bybelse perspektiewe}

By die oorweging van eutanasie in 'n Bybelse perspektief kom die volgende twee vrae aan die orde: Wat is die sin van 'n mens se lewe? En: Wat is die sin van menslike lyde? Albei die vrae kulmineer in die vraag: Hoe moet die nuttigheid van die ongeneesbare siek mens gesien word? Kan die lewe van 'n sogenaamde nuttelose mens beëindig word?

Oor die sin van die mens se lewe word in die Bybel soos volg geoordeel:

- Die mens is die beelddraer van God. Volgens die kultuurmandaat van Genesis 1:26-28 word die mens deur God aangestel as heerser oor die skepping. Hy/sy moet dit wat God goed geskape het beskerm, bewaar en onderhou. Konkreet gesien, beteken dit dat die mens uit die natuur kultuur moet skep en versorgend en opbouend besig moet wees.

- Hierdie opdrag gaan nie met die sondeval tot niet nie. Hoewel die mens se vermoëns deur die sonde geskend is, bring God in Christus vernuwing. Die ou mens word 'n nuwe mens wat soos 'n nuwe mens moet leef (Kol. 3). In hierdie proses ontvang die mens die bystand van die immerteenwoordige Gees van God (1 Kor. 12:1-11). 
- So belangrik is die kultuur van die mens dat sy/haar werke tot in die Nuwe Jerusalem sal bestaan (Op. 21:26).

Uit die voortgang van die Bybelse openbaring moet dus afgelei word dat die bestaan van elke mens sinvol is. Nêrens in die Bybel word getuig dat die mens 'n nuttelose bestaan voer nie. Ongeag die mens se omstandighede bly hy/sy altyd medewerker van God om te bou, te bewaar, te beskerm en te getuig. Die mens se bestaan in hierdie bedeling word nooit sinloos nie.

Oor die sin van lyde word eweneens duidelike uitsprake gelewer:

- Lyde kom van God af (vgl. die Jobverhaal).

- Lyde word deur God gebruik in die opvoeding van sy kinders tot groter geloof en vertroue (Deut. 32:10-12; Jak. 2:1-8).

- Lyde word deur God ook aangewend as tugtiging van dié wat hy liefhet (Heb. 12:4-8).

- Lyde word oor die gelowige gebring ten einde hom/haar in staat te stel om oor God te getuig (Fil. 1:12-14). Die lydende kan die geloof van mense om hom/haar opbou.

- Lyde moet gedra word wanneer die mens goed doen (1 Pet. 2:21-24; 3:13-17).

- Lyde is deelgenootskap aan die lyde van Christus (1 Pet. 4:1 en 2; $4: 12-16)$.

'n Voorbeeld van hoe 'n mens die status van lydendes moet sien, kan afgelei word uit die optrede van Christus. Christus het mense nie gegroepeer volgens sosiale klas, stand, ouderdom of aanvaarbaarheid in die samelewing nie. Hy het menslike diskriminasie deurbreek. Hy het hom bemoei met die armes, melaatses, tollenaars, verlamdes, besetenes, die blindes en die dowes. Hy het hom in die besonder gerig tot die mense wat ly en swaarkry en vir alle soorte mense 'n plek in die koninkryk bestem (sien hieroor Douma, 1996:221 en Banner, 1998:27). In die herskepping is almal gelyk en kom daar sin in elkeen se bestaan. Ook in die kerk as liggaam van Christus word tussen mense onderskei op grond van die gawes wat die Heilige Gees gee en nie op grond van geslag of menslike vermoëns nie.

Uit bogenoemde Skrifgedeeltes kan afgelei word dat die mens se lewe altyd sinvol is en dat geloof nie altyd voorspoed beteken nie, maar ook sinvolle lyde. Lyde vernietig nie die mens se beeldskap van God nie. Om te verklaar dat ' $n$ mens nutteloos kan word en dat lyde geen sin het nie, kan nie Bybels gefundeer word nie. 


\subsection{Etiese perspektiewe}

In die etiese beoordeling van eutanasie moet met verskeie nuanses rekening gehou word. Enkele onderskeidings is belangrik. Eerstens word betoog vir die onderskeiding tussen die beëindiging van die lewe met die toestemming van die pasiënt en die beëindiging van die lewe sonder die toestemming van die pasiënt. Eersgenoemde sou dan aanvaarbaar wees en laasgenoemde onaanvaarbaar. Die reg word bepaal deur die pasiënt self. Oor eutanasie sonder die toestemming van die pasiënt sê Douma (1996:221) dat die mens op hierdie wyse vir homself/haarself 'n reg opeis wat net God toekom. Die mens word die regter oor lewe en dood en moet dan volgens sy/haar eie maatstawwe oor die belang van ander se lewe oordeel. Gestremde en terminaal siek mense moet beoordeel word met God se maatstawwe en nie die mens se maatstawwe nie. In Christus maak God met alle mense bemoeienis, ongeag siekte of gestremdheid en dieselfde gesindheid moet in mense wees.

Dieselfde argument is egter ook van toepassing by eutanasie met die toestemming van die pasiënt. Verder kan eutanasie met die toestemming van die pasiënt as "selfmoord met die hulp van iemand anders" beskou word en dieselfde argumente teen selfmoord moet dan ook hierop van toepassing wees (vgl. oor selfmoord De Bruyn, 1998:133; Wood, 1986: 609). Die medikus Allman (1998:21) betwyfel vanuit die mediese wetenskap die geldigheid van die toestemming. Hy vra: "Is the depressed, frightened, lonely, pain-ridden patient really autonomous?" Kan 'n mens in lyde werklik 'n verantwoordelike keuse maak? Dan plaas hy ook 'n vraagteken agter die begrensing van die reg op 'n keuse (Allman, 1998: 22). Waar word die streep getrek? In welke mediese gevalle mag so 'n keuse uitgeoefen word?

Die tweede onderskeiding is die onderskeiding van aktiewe en passiewe eutanasie soos Fischer (1996:111) dit aan die orde stel. Om dieselfde saak aan te dui onderskei Douma (1996:223) tussen die beëindiging van lewe (aktiewe eutanasie) en die beëindiging van behandeling (passiewe eutanasie). Die handeling waar die lewe van die pasiënt met die hulp van ander aktief beëindig word, moet afgewys word op grond van dieselfde argument wat teen doodslag en selfmoord aangevoer word. Die mens het nie die reg om lewe te neem nie. Oor die staak van behandeling kan, onder bepaalde voorwaardes, anders geoordeel word. In sulke gevalle moet bepaal word of die lydende nie kunsmatig aan die lewe gehou word nie. Indien wel, kan behandeling gestaak word. Wanneer iemand breindood verklaar word, moet dit nie gesien word as passiewe eutanasie nie, want die persoon is dan dood ( $\mathrm{vgl}$ in hierdie verband Lategan, 1991:54 en De Bruyn, 1998:132). 
In wese kan eutanasie nie anders beoordeel word as "selfmoord deur die lydende self" en die neem van 'n lewe deur die ander betrokkenes nie. Albei is in stryd met die Bybelse gebod dat die mens nie 'n lewe mag neem nie.

\section{Konklusie}

Die teenswoordige beklemtoning van die reg op lewe as 'n fundamentele reg in die menseregtedebat moet vanuit Christelik-etiese hoek ondersteun word. Die reg op lewe en die plig om lewe te bewaar, is 'n duidelike Bybelse beginsel. Die toenemende wettiging van aborsie op aanvraag, die toepassing van die doodstraf en die toelating van eutanasie as die beëindiging van lewe is egter in stryd met die reg op lewe. Die Christen moet ander weë soek om met die problematiek onderliggend aan hierdie lewensonterende praktyke om te gaan. Ten einde aborsies te verhinder moet die Christelike seksuele etiek, gesinsbeplanning en die aanneming van kinders deur kinderlose ouers kontekstueel uitgewerk word. Om bevooroordeelde doodstraf en die moontlike misbruik daarvan deur die owerheid uit te skakel behoort lewenslange gevangenisstraf eerder as doodstraf gepropageer te word. Ten opsigte van eutanasie moet die Christelike etiek die nuttigheid van die mens in die oë van God en die sin van lyde duidelik aan die orde stel. Sodoende sal die reg op lewe konsekwent toegepas word.

\section{Bibliografie}

ALLMAN, R.L. 1998. Euthanasia and physician-assisted suicide: A non-conformist Reformed reflection. The Journal of Pastoral Care, 52(1):19-31.

AVALOS, L. 1999. Hindsight and the abortion experience. Gender Issues, 17(2):3558.

BANNER, M. 1998. Christian anthropology at the beginning and the end of life. Scottish Journal of Theology, 51(1):22-60.

BECKWITH, F.J. 2001. Law, religion and the metaphysics of abortion: A reply to Simmons. Journal of Church and State, 43(1):19-34.

BONDOLFI, A. 1999. Death penalty. (In Fahlbush, E., ed. The Encyclopedia of Christianity. Vol. 2. Grand Rapids : Brill. p. 784-788.)

BOTHA, J. 1991. Reading Romans 13. Aspects of the ethics of interpretation in a controversial text. Stellenbosch : Universiteit Stellenbosch. (Ongepubliseerde D.Th.-proefskrif.)

BROWN, M.T. 2000. The morality of abortion and the deprivation of futures. Journal of Medical Ethics, 26(2):103-108.

CALVYN, J. 1949. Institutie. Volume 3. Meinema : Delft.

CALVYN, J. 1847. Commentaries on the first book of Moses called Genesis. Edinburgh : Calvin Translation Society.

CHIRAC, J. 2001. Speech by Jaques Chirac, President of the French Republic before the United Nations Commission on Human Rights. Geneva : United Nations.

DE BRUYN, P.J. 1998. Die Tien Gebooie. Potchefstroom : PU vir CHO. 
DE VAUX, R. 1988. Ancient Israel: Its life and institutions. Translated by John McHugh. London : Darton, Longman \& Todd.

DIENG, A. 1997. Editors note. Human Rights Quarterly, 19:165-170.

DINN, J. 2000. What does the church say about capital punishment? U.S. Catholic, 65(12):32-34.

DOUMA, J. 1996. The Ten Commandments, manual for the Christian life. Translated by N.D. Kloosterman. Philipsburg : P. \& R. Publishing.

DRIVER, S.R. \& GRAY, G.B. 1921. A critical and exegetical commentary on the book of Job, together with a new translation. Edinburgh : Clark.

DUNN, J.D.G. 1988. Romans 9-16. Word biblical commentary vol. 38. Dallas : Word Books.

FISCHER, J. 1996. Aktive und passive Sterbehilfe. Zeitschrift für Evangelische Ethik, 40(4):110-127.

GAIE, J.B.R. 1996. The Christian view on capital punishment. African Ecclesial Review, 38(1):362-375.

GROSS, M.L. 2000. Avoiding anomalous newborns: preemptive abortion, treatment thresholds and the case of baby Messenger. Journal of Medical Ethics, 26(4):242-249.

HAMILTON, V.P. 1991. The book of Genesis, chapters 1-17. Grand Rapids : Eerdmans.

HARTLEY, J.E. 1988. The book of Job. The new international commentary on the Old Testament. Grand Rapids : Eerdmans.

INTERNATIONAL COMMISSION OF JURISTS. 1997. Administration of the death penalty in the US. Human Rights Quarterly, 19(1):171-213.

JEFFREY, K. 1999. Helping women with post-abortion. The Journal of Biblical Counselling, 17(3):27-29.

KRESS, H. 1999. Personwürde am Lebensbeginn, Gegenwärtige Problemstellungen im Umgang mit Embryonen. Zeitschrift für Evangelische Ethik, 43(1):36-51.

LaFLEUR, W.R. 1998. Abortion, ambiguity and exorcism. Journal of the American Academy of Religion, 67(4):797-807.

LATEGAN, L.O.K. 1991. Genadedood of dood sonder genade? Bloemfontein : VCHO.

LEE, P. 1996. Abortion and human life. Washington : Catholic University of America Press.

RHEEDER, A.L. 1999. Selektiewe voortplanting by die mens. Potchefstroom : PU vir CHO. (Th.D-proefskrif.)

SIMMONS, P.D. 2000. Religious liberty and abortion policy: Casey as 'Catch 22'. Journal of Church and State, 42(1):69-88.

STRETTON, D. 2000. The argument from intrinsic value: a critique. Bioethics, 14(3):228-239

SULLINS, P. 1999. Catholic/Protestant trends on abortion: convergence and polarity. Journal for the Scientific Study of Religion, 38(3):354-369.

TRISTAN ENGELHARDT, H. 1998. Physician-assisted death: doctrinal developments vs. Christian tradition. Christian Bioethics, 4(2):115-121.

UNITED NATIONS. 1995. The United Nations and human rights 1945-1995. Genéve : United Nations.

URSINUS, Z. \& OLEVIANUS, C. 1992. Die Heidelbergse Kategismus. (In Gereformeerde Kerke in Suid-Afrika. Die berymde psalms, belydenisskrifte en liturgie. Potchefstroom : Calvyn Jubileum Boekefonds.)

VAN SELMS, A. 1952. Job 1. De prediking van het Oude Testament. Nijkerk : Callenbach. 
VAN WYK, J.H. 1991. Moraliteit en verantwoordelikheid, opstelle oor die politieke etiek. Potchefstroom : PU vir CHO.

VORSTER, J.M. 2000. A contemporary principle for Christian ethics in view of prominent historical paradigms. Studia Historia Ecclesiasticae, XXVI(2):1-23.

WENDLER, D. 1999. Understanding the 'conservative' view on abortion. Bioethics, 13(1):32-55.

WENHAM, G.J. 1987. Genesis 1-15. Word Biblical Commentary. Waco : Word Books.

WESTERMANN, C. 1972. Erträge der Forschung, Genesis 1-11. Darmstadt : Wissenschaftliche Buchgesellschaft.

WESTERMANN, C. 1986. Genesis 1, Een praktische bijbelverklaring. Kampen : Kok.

WOOD, T. 1986. Suicide. (In Childress, J.F. \& Macquarrie, J., eds. The Westminster dictionary of Christian ethics. Philadelphia : Westminster Press. p. 609-610.)

WÜSTENBERG, R.K. 1998. A theology of life. Dietrich Bonhoeffer's religionless Christianity. Grand Rapids : Eerdmans.

Kernbegrippe:

aborsie

die reg op lewe

doodstraf

eutanasie

reg op lewe

Key concepts:

abortion

capital punishment

death penalty

euthanasia

the right to life 